Article

\title{
Thank God We Are Creatures: Hannah Arendt's Cryptotheology
}

\section{Rafael Zawisza}

Faculty of Artes Liberales, University of Warsaw, ul. Nowy Świat 69, 00-046 Warszawa, Poland; rafal.w.zawisza@gmail.com

Received: 1 October 2018; Accepted: 13 November 2018; Published: 19 November 2018

check for updates

\begin{abstract}
Main concern of this article is to grasp the interpretative matrix of Hannah Arendt's doctorate, which, I claim, is the central organising net for her other writings. I call this matrix "cryptotheological defence of the secular world". In order to show its functionality, I have to determine the character of Arendt's discourse in relation to theology and philosophy on the basis of her doctoral thesis from 1929. The main attention will be focused on the figure of the neighbour as a singular and the concept of natality. I will show how the critique of theology, often very ironic, serves Arendt to contest the paradigm of the political theology.
\end{abstract}

Keywords: Hannah Arendt; Augustine of Hippo; creatureliness; neighbour; post-secularism; cryptotheology; marrano; transcendence; singularity

Die Welt war schlechthin unabsolut geworden. Nicht bloß der Mensch, nein auch Gott konnte außer ihren Grenzen, wenn anders er wollte, Platz finden. Diese metalogische Welt bot aber, gerade weil sie gottlos war, keinen Schutz gegen Gott.

Franz Rosenzweig, Der Stern der Erlösung (Rosenzweig 1921, p. 23)

After having read numerous texts about Hannah Arendt's doctoral thesis Der Liebesbegriff bei Augustin, I came to a conclusion that we need a new interpretation of it. It is a rule that scholars insisting on Arendt's secularism do not have an idea how to integrate the confusing dissertation into her oeuvre. There is a temptation to avoid this inconvenience by stating that between the doctorate and her next major work, The Origins of Totalitarianism - which means between 1929 and 1951-there was a decisive break. I am not going to contest the facts and claim that there was no change, that the horrific time of totalitarian rulership, exile, and war did not put an imprint on Hannah Arendt. But to announce the break and neglect her first work would be nothing but an excuse. An excuse that makes her work easier to understand, even to use or widespread, nonetheless it would mean that a galvanised image of Arendt as political theorist will become more and more a cliché and an obstacle to revive her thought for future generations.

There is no historical evidence of what motivated Hannah Arendt to choose the topic of the dissertation. Laure Adler claims that it was meeting Rudolf Bultmann at his seminar on the New Testament, which coloured Arendt decision. It was apparently thanks to him that she discovered Augustine for herself (Adler 2008, p. 62). However, other scholars insist on the primary role of Heidegger. Jacques Taminiaux intended to show that Heidegger's lectures on Aristotle made an impression on the young Arendt (Taminiaux 1997). Luca Savarino attempted to underline an impact of Heidegger's lectures from 1920 to 1921 (introduction to the phenomenology of religion as well as the lecture about Augustine and Neo-Platonism), although Savarino emphasises that there is no certainty whether Arendt was familiar with the content of those lectures, which she did not attend (Savarino 1999, pp. 251-61). Various influences do not exclude each other, which is why one may 
also mention Hans Jonas, who as a very good friend of Arendt's was elaborating his thesis Augustin und das paulinische Freiheitsproblem: Ein philosophischer Beitrag zur Genesis der christlich-abendländischen Freiheitsidee, finished in 1930.

Hannah Arendt's doctoral dissertation was defended in autumn 1928 in Freiburg and published by Julius Springer in Berlin in 1929 under the title Der Liebesbegriff bei Augustin: Versuch einer philosophischen Interpretation. It was part of a series which was soon to be closed and where Karl Jaspers helped his students to publish their thesis. Scarcity of time, which Arendt complained to Jaspers about, could explain the dense and inconclusive character of the third part: Vita socialis. However, there were graver problems that the young author encountered and somehow left unresolved, while still being able to draw up a map, which would delineate her later concerns.

For hermeneutical reasons, there is one decisive issue I have to explain at the start. Hannah Arendt worked on the translation of her dissertation into English in the late 1950s and early 1960s. It was a translation by Ernst Basch Ashton, which she received to approve and which she corrected a lot, going as far as to amend the whole text, except the last part, Vita socialis, which she left unchanged. Again, it is not certain why Arendt gave up at certain point, as a result of which the translation needed to wait for publication until 1996. In a letter from 20 October 1965 to Mary McCarthy, Arendt gave an impression of how she felt about the encounter with her prewar text:

I got myself into something absurd-Macmillan had asked me years ago for my dissertation on Augustine. I needed the money (not really, but could use it) and said yes. The translation arrived two years ago and now I ran out of excuses and have to go over it. It is kind of a traumatic experience. I am re-writing the whole darned business, trying not to do anything new, but only to explain in English (and not in Latin) what I thought when I was twenty. It is probably not worth it and I should simply return the money-but by now I am strangely fascinated in this rencontre. I had not read the thing for nearly forty years. (Arendt and McCarthy 1995, p. 190)

The differences between the German original from 1929 and Arendt's amendments from the 1950s and 1960s to the English translation of her dissertation constitute a topic in itself. Here I analyse the final shape of her doctorate, claiming that its complex development only confirmed that what Arendt had written in the late 1920s then became the cryptotheological matrix, where initial intuition only crystallised and from which it was widespread throughout her various writings. I am persuaded that scrupulous, "Talmudic" work on the comparison of the German and English editions, all existing corrections included, is necessary and that it is a work waiting for its author. Yet, as for the aim and structure of my thesis, this is not of high importance. First of all, the most essential part of Arendt's dissertation, namely the third chapter entitled Vita socialis, was published in English edition as a direct translation of the original from 1929, because Arendt did not introduce any changes to this part. As for the two previous chapters, I analyse original as well as added fragments, treating them as one migrating entity. What I mean by that is that the ideas present in the first edition were only developed more fully in the 1950s and 1960s, thus there is no break or shift that could make this historical process of migration of ideas problematic for my reconstruction. What constitutes the genuine shift already in the 1920s is Vita socialis. To summarize, I was considering dividing the material by commenting on the original and on the amendments separately, but I decided that the advantages of this option are few and the risk of producing chaos-quite predictable (due to necessity of constantly clarifying which version of Arendt's dissertation I refer to-and then to integrate some complex lines of argumentation). In my opinion, natalism is the undercurrent of Arendt's thought, originating in her doctoral thesis, that is why it is not controversial to see this in holistic perspective. What would be of high importance is to grasp the moments in her texts written after publication of The Origins (1951), which were influenced by her return to her dissertation since the 1950s. I only mark this fact here in order to demonstrate the processes of translations and transmissions. The specific texts at stake are the last chapter of The Origins-Ideology and Terror-added to the second edition (1958) but written in the middle in the 1950s as well as The Human Condition (1958). On Revolution (1963) in this perspective appears as the elaborate response to the dilemmas and aporias which haunted Arendt when she was preparing Vita socialis. 
Richard Wolin calls Arendt's dissertation "a strikingly un-Arendtian document ( . . ) [in which-RZ] the inflections of her mature philosophical voice are barely audible. It is a work of a disciple, narrowly textual in orientation and focus, devoid of the originality that would characterize her subsequent work" (Wolin 2001, pp. 42-43). Wolin disregards the fact that the whole Arendtian anthropology was germinating in her first book. He uses schematic explanation, which shows how little he understood from Der Liebesbegriff; Wolin thinks that because of Augustine's otherworldliness, young Arendt—as lost in Augustinian worldview—could not be reconciled with her later insistence on worldliness. In sum, he overlooks that it was precisely in Augustine that Arendt intended to find commitment to the world despite having declared rejection of it. His second argument, that transcendence contradicts plurality, also shows rather Wolin's own misconception and in consequence it obnubilates Arendt's dialectic attitude towards theological tradition. Only on the basis of his interpretative failure could Wolin not only separate Der Liebesbegriff from her later thought, but he could also claim that in Rahel Varnhagen Arendt rejected her first work as concentrated on introspection (Wolin 2001, p. 44). I would rather insist that despite her scepticism about the force of inwardness, she did not dismiss its role altogether.

Kurt Sontheimer found Der Liebesbegriff more promising, calling it "the first important, but not particularly original step towards intellectual independence" (Sontheimer 2005, p. 31). It is characteristic that the dissertation is underestimated either by the secular interpreters, or by theological ones, who have a tendency to ascribe everything valuable to Augustine and see Arendt in a minor position of, for example, Heidegger's "child" or Augustine's "daughter". John Kiess, as one of the few commentators representing theology, felt compelled to protest against those attempts at diminishment: "as with Heidegger, Arendt appropriated and criticized elements of Augustine's work with the same spirit of independence that will mark her engagement with many other thinkers" (Kiess 2016, p. 21). It is even more than to say that Arendt was "a qualified Augustinian" (Clarke and Quill 2009, p. 254).

It is not unimportant how we understand Arendt's stance towards the Augustinian legacy, and later, how we estimate what happened after World War II at her first encounter with Augustine's thought. I agree with Joanna Vecchiarelli Scott, who states that Arendt's perseverating references to Augustine "are central to her argument and cannot be easily dismissed as scholastic decoration or the afterglow of an early flirtation with idealism for the most part outgrown" (Vecchiarelli Scott 1988, p. 398). As we will see, Arendt built on a certain logic of thought already inscribed in her doctoral thesis. "This text-Étienne Tassin writes—is seminal: it fecundates [irrigue] all the future works, including capturing the distance which it induces" (Tassin and Albanel 2010, p. 11). It was, however, not only the logic of argumentation, but also the set of problems she found in Augustine which she regarded as pressing on her own contemporaneity. The questions were not so much originally Augustinian, but rather revived in different thematic constellations. That is why I abstain from calling Arendt an Augustinian of any sort. She deeply distorted his reflections and did not read him as a theologian. Those who regard Der Liebesbegriff as a work dependent on Augustine and theology are probably confused by its form, un-Arendtian indeed. If one does not follow the lines of argumentation rigorously and does not pay attention to the details, it seems that the author of the dissertation is a commentator of the great thinker of the past. By quoting Augustine extensively, Arendt made the impression that she was totally immersed into the analysed material. But this was precisely her strategy: to show, through close reading, inconsequences and aporias. They would not appear as problematic points without Hannah Arendt's unique position of speaking, which gave her freedom to compose Augustine's thought in the way she did it and not otherwise. Arendt's seemingly "humble" role of commentator submerged her extremely critical voice. Yet, again, this voice is so subtly ironic and her criticism so embedded in the structure of the book, that it is easy to disregard it.

Apart from the problem of inventiveness of early Arendt, there are two other issues: her potentially political stance and her attitude to theology. Ronald Beiner writes: "What the Augustine book may indicate is that Arendt was a political philosopher before she knew that she was one" (Beiner 1997, p. 270). My task is to radicalise this statement by showing how deeply political her earliest concerns 
about the love of the neighbour and relations of the individual torn between God and world were. ${ }^{1}$ I am not going to contest the thesis that Rahel Varnhagen's biography was Arendt's first political book, properly speaking (Armenteros 1999, p. 86), and indicated the period when she became politically conscious and began to deal seriously with history, law, and politics. Yet, I strongly disagree with Carolina Armenteros' unjust qualifications of Der Liebesbegriff as a "highly abstract existential exercise" (Armenteros 1999, p. 87).

Arendt's doctoral thesis has much to offer when it comes to an anthropology of political theory, i.e., more "pre-political" or "meta-political" reflections; however, this does not mean that it is less relevant in that regard. Conversely, what I call "pre-political" is what was reflected by Arendt herself under the term "pre-theological sphere" (die vortheologische Sphäre; Arendt 1929, p. 3). The sphere prior to any religion and its theological self-understanding constitutes a battlefield with the paradigm of political theology, which makes politics dependent on certain theological origin.

It is probably not astonishing that Arendt's dissertation has not found its full recognition. Among both religious and secular commentators there is no agreement whether young Arendt was more theological or philosophical. I found some paradox as indicative, namely that a Jesuit claims that "Hannah Arendt never writes theology" (Boyle 1987, p. 96), while a secular scholar does not hesitate to report about "Arendt's youthful flirtation with theology" (Moyn 2008, p. 71). Some resolution would be to count Arendt among "nontheologians practicing theology" (Biale 2011, p. 9), as David Biale shortened Amos Funkenstein's definition of the "secular theology". However, what interests me the most is "her consequent ability to live with creative confusion" (Neiman 2001, p. 72). That is why I am inclined to think about Hannah Arendt as a representative of the group named by Agata Bielik-Robson "the philosophical Marranos" (Bielik-Robson 2014).

Only by referring to this complex approach it would be possible to reintegrate Der Liebesbegriff within the context of politico-theological debates of the Weimar period..$^{2}$ In order to do that, however, a move backwards is necessary, which grasps the dissertation in its microcosm. The subtlety necessary to decipher Arendtian cryptotheological secularism usually escapes theological interpretations. ${ }^{3}$ Even though secular interpretations are closer to the point, they remain incomplete without acknowledgement that, in defending secularity, Arendt sought help by both secular and theological means. That is why Samuel Moyn in his otherwise excellent article about Arendt and the secular marvels over the fact that she acceded biblical provenance for the model of political promise and calls this idea "rather shocking" (Moyn 2008, p. 86). The concept of natality poses a similar difficulty for Moyn, as he thinks that it is too religiously burdened and because of that it incurs a risk of the Schmittian critique (Moyn 2008, p. 96). I claim exactly the opposite: that Arendt's familiarity with theology and her philosophy of birth makes the attack on the political theology all the more crushing. Political theology is deconstructed by the introduction of the third element, preceding both theology and politics: anthropology. What is more, the appreciation of the human birth in its anti-naturalist specificity serves to contest the political implications of the doctrine of the original sin, on which Christian political theology relied.

1 For the picture of the tensions in Weimar Germany due to religious divisions, see the sociological-historical summary of Todd H. Weir (Weir 2015). He depicted intrareligious battles, but also a campaign against secularism, which helped Hitler come to power. The author also described the Catholic ambivalent reaction to Nazism and vice versa, the reasons why Protestants supported Hitler more than Catholics, or how Catholics mimed communist organisations in order to combat them. What is missing in Weir's article is the role of the Jews.

2 The first step in this direction was already taken, see (Chacón 2012).

3 The discussion about Arendt and theology did not reach full-scale until Jesuits from Boston edited the volume Amor mundi (Bernauer 1987a). Nevertheless, there was no further resonance, probably because this volume, containing many deep insights notwithstanding, is charged by apologetic intentions. 


\section{Pretheological Sphere}

Arendt's dissertation was "guided by the question of the meaning and importance of neighbourly love in particular" (Arendt 1996, p. 3). Knowing her sense of irony, this could implicitly indicate that despite the fact that this was one of Augustine's central concerns, his theological vision of God and its philosophical antecedences had overridden essentiality of the neighbour. The fact that Arendt's recapitulation of Augustine's views was intended to be an accompanying critique from the very beginning is reinforced by the following statement:

Augustine's every perception and every remark about love refer at least in part to this love of neighbor.

Thus the question about the neighbor's relevance always turns into a simultaneous critique of the prevailing concept of love and of man's attitude toward himself and toward God. (Arendt 1996, p. 3)

Taking into account her overall deconstruction of the Augustinian concepts, Arendt could not have been much more overt about her intentions in the introduction. Otherwise, it would have been seen as a gross effrontery—after all, she was just a doctoral student at that time. ${ }^{4}$

Arendt's initial remarks conceal a polemical approach, without the detection of which the whole interpretation of her work would bog down. She very often pretended that she was just summarizing Augustine's ideas, while in fact she adopted his views in order to turn them against themselves. For instance, when she said: "This critique will never be an absolute critique from some fixed philosophical or theological standpoint. It is a critique only because the respective concept of love claims to be a Christian one" (Arendt 1996, p. 3). In other words, Arendt's intention is to check to what extent Augustine's argumentation sticks to the teachings of Christianity.

She estimated that Augustine had been "truly religious rather than determined by Neoplatonic Greek influences" (Arendt 1996, p. 4). By saying that Arendt only payed off a debt to biographical truth, to Augustine's inner intentions, ${ }^{5}$ which, however, did not find its road to fulfilment throughout Greek categories. ${ }^{6}$ Heterogeneous influences together with "heterogeneous intentions" brought about the effect of "disjointedness", and for that reason Arendt applied her "systematic approach in detail" so that "a substantially common base" (Arendt 1996, p. 4) could be grasped. In no case did she intend to synthetize Augustine's divergent trains of thought—on the contrary, she made crevices on this common surface perfectly visible, without any attempt to reconcile them in antithetical or dialectical form. The ironic impetus of Arendt's analysis employs what we could call "double negative dialectics", 7 which is able to maintain contradictions in motion, following life's own rhythm that defends itself from stopping, ending, and dispersing.

Nonetheless, irony does not exclude seriousness, related to this so far quite mysterious "substantially common base" located within "pretheological sphere". Ironic impulses serve to uncover it, yet not allowing to determine it as the ultimate ground. On the other hand, as we will see later, it is just because of this ultimate, drifting ground that the common base could appear as common. Arendt's interpretative strategy relies on "making explicit what Augustine himself has merely implied", meaning that in order to treat him more seriously, one needs a detachment from "Augustine's dogmatic

4 I would not, however, go so far as Richard Wolin did, who says: "In certain respects, the work stand out as an embarrassing testimonial to the delusions of assimilationism. It was written at a point in Arendt's life when she still entertained hopes of a university career amid the woefully conservative milieu of German academic mandarins" (Wolin 2001, p. 43). As reflected in her prewar letters with Jaspers, Arendt was very straightforward and fierce in her critique. She quarrelled with Jaspers about his political stance towards Jews in the 1930s. Moreover, Hans Jonas preserved a memory of her audacious behaviour at the university: before joining Rudolf Bultmann's seminar on the New Testament, she as a Jew wanted to make sure that she would not listen to anti-Semitic remarks. Joanna Vecchiarelli Scott poses a rhetorical question, asking who among the Weimar era students dared behave so boldly towards the mandarins of German academia (Vecchiarelli Scott 2010, p. 16)?

5 "For Augustine this relevance [of the neighbour-RZ] was simply a matter of course" (Arendt 1996, p. 4).

6 Arendt explained one of the aporias found in the analysed texts by saying that "the reason for this incongruity lies in Augustine's terminology, which he took from the tradition of Greek philosophy even when he wished to express experiences that were quite alien to it" (Arendt 1996, p. 12).

7 Derived from simultaneous absorption and negation of life's "not yet" and "no more": "This questioning beyond the world rests on the double negative into which life is placed" (Arendt 1996, p. 70). 
subservience to scriptural and ecclesiastical authority" (Arendt 1996, p. 4). The thing which from a dogmatic position seems to be ironic, blasphemous, and heretic, could actually be a polemical struggle for true seriousness (in this case: in treating one's own neighbour). Nevertheless, Arendt did not defend any polemics with orthodoxy as simply justified in itself thanks to be antidogmatic. This is crucial, because it is hard to attack her stance as simple reversal, revaluation of values, etc. Instead, she admitted that "such intentional detachment from all dogmatic elements may doom the interpretation of a religious author, but is relatively easy to justify in Augustine's case" (Arendt 1996, p. 4).

The way that Arendt emphasized autonomy of the secular realm against the divine one is so subversive that one can probably understand the following conclusion only as an excuse that could have left a naïve reader mistaken: "Of course, these presentations will not prove whether, in fact, such a pretheological sphere is to be justified as all, or whether the possible being or not being of human existence is truly settled in God's presence" (Arendt 1996, p. 6). Partially, this statement could signify that Arendt's "attempt at an inquiry of purely philosophical interest" (Arendt 1996, p. 6) -as she called her dissertation-does not encroach upon territory reserved for theology. But it is not clear how Arendt could maintain the purity of this division, since she acknowledged that even in his most religious writings Augustine "never wholly lost the impulse of philosophical questioning" (Arendt 1996, p. 6). Moreover, in Der Liebesbegriff the essential theoretical battles were conducted precisely in the midst of theology, using theological reasoning, drawing conclusions from it to the point of absurdity.

That Arendt manoeuvred between secular and religious reading of theological discourse, provoking its destabilisation, becomes visible in her introduction of the term the "pretheological sphere". It is not only that she assumed that theological edifice rests on philosophy, but-more profoundly - that it always rests on a certain anthropology, as it derives from anthropological sources, and finally from the time out of mind. That is why, according to the double negative dialectics, she secularised theology, and granted religion a position higher than earthly authority, at the same time dismantling the theocratic stalemate with this singular move. By this I mean that she extracted the most precious element from theology in order to catapult it into "heavens" of ideals. The religious experience and theological discourse are not excluded, but separated. The former concerns strictly inner reality, the latter would inspire the world if it only could illuminate existence without demanding a certain credo. Since the second option is barely possible, Arendt chose a philosophical "contraband" instead of a reversal of theology. Those restrictions explain why Arendt's immediate reaction to any possibility of the absolute to appear consisted of strengthening divisions and buffer zones. Arendt quoted Augustine:

They have not understood that 'Do not do to another what you do not wish to have done to you', cannot be varied in any way by any national diversity of customs. When this rule is applied to the love of God, all vices die; when it is applied to the love of our neighbor, all crimes vanish. (Arendt 1996, pp. 4-5)

However, Arendt's comment distorted the Augustinian text beyond recognition. She wrote:

Preceding the express commandment of neighborly love is another that is independent of any such explicit divine revelation that has become real in Christ. This is the 'law written in our hearts.' The Christian commandment sharpens this 'natural' law, and thus enhances the human community to its highest reality in which all crimes are extinguished. Therefore, we shall be able to limit the scope of interpretation in two ways without being dogmatic. First, we shall ask about this pretheological sphere. Second, we shall seek to grasp what Augustine's exegesis would regard as the specific novelty in the Christian elaboration. (Arendt 1996, p. 5)

Here, her reading of Augustine, the anti-Pelagian author, is thoroughly Pelagian. In the first quotation, that from Augustine, divine law implants itself on the common moral basis, free from cultural contexts; it is a narrative conducted by the demands of the economy of salvation, which explains how the 
Christian faith only strengthens what was already prepared within pagan ethics, waiting for the divine message. Arendt did not undermine this narrative, she just changed perspective: if a "law written in our hearts" lasted for centuries without Christian revelation, this undoubtedly means that it was independent from any revelation. "Through philosophical work with ideas the author wants to justify her freedom from Christian possibilities, which also attract her" (Arendt and Jaspers 1992, p. 690)—as Karl Jaspers wrote in a review, being the supervisor of Arendt's thesis. That is why she emphasised the element as autonomous from excessively demanding Christian ethics, not calling it "pagan" or "Jewish", but rather- "the pretheological", prior to any institutionalized religion, the "natural, prereligious, and secular law" (Arendt 1996, p. 39). Her reservation regarding Christianity is full of respect and justified only from the point of view of a Marranic cryptotheology that Arendt secretly activated in her dissertation. The Christian message is renounced not because it is false, but because it is all too soon. ${ }^{8}$ Double negative dialectics allows to keep divinity at distance ${ }^{9}$, which is not necessarily an atheistic gesture, but a more pious one than that which is usually taken as religious. To keep God at distance implies prevention of any divinisation of earthly reality. This is the reason why Arendt took "natural" in quotes, using the term "'natural' law" (Arendt 1996, p. 5) ${ }^{10}$ (even though in this particular context this natural law would be in tune with her defence of secularity). However, secularity in this version is devoid of sanctity: consequently, secularisation could not be equalled with a robbery, usurpation, or inheritance of any sacral "property". Thus, a "substitutional dilemma" (Moyn 2008, p. 77) could be avoided and not neglected.

\section{Nature}

De-divinization of nature by means of the notion of transcendent God governs the thinking of Franz Rosenzweig, who was the greatest unmentioned precursor of Arendt when she was preparing Der Liebesbegriff. For Rosenzweig, nonidentity of "world" and "nature"11 (Rosenzweig 2005, p. 23) protects a human being's freedom, ultimately guaranteed in the analogous, paradigmatic separation of God from the world:

The condition of creature, which we have claimed for the world in order to save the selfness of man, therefore let God, too, escape from the world. Metaethical man is the fermentation that breaks down the logical and physical unity of the cosmos into the metalogical world and the metaphysical God. (Rosenzweig 2005, p. 22)

For man confronted face to face with nature renders to be "not a creature, but a part" (Arendt 1996, p. 69), a part of nature whose totality obtrudes as crushing if there is nothing to counterbalance it. It obtrudes itself upon individuality to the extent that it hollows inwardness out, resulting in the denigration of the subject. On the contrary, Arendt emptied individuality out of natural content, leaving free space for ethical life. "If he [man-RZ] could be said to have an essential nature at all, it would be lack of self-sufficiency" (Arendt 1996, p. 19). It means that the human condition is undetermined,

8 I will demonstrate the validity of the terms "Marranic" and "Judeochristian" later. Here I may add a hypothesis, which I am unable to prove within the scope of this text, but which, nonetheless, inspired my interpretation, namely that the model of Arendt's hidden theological imagination could be found in the idea of a withdrawn God (tzimtzum) as it is known from the Lurianic Kabbalah. The hypothesis is verifiable textually through Arendt's intellectual exchange with Gershom Scholem, which started in the late 1930s. As for the earlier possible sources of this influence one could indicate Franz Rosenzweig. It is also not excluded that Arendt might have inherited certain heterodox ideas through German idealism, especially via dialectical theology, and if so, the term "Judeochristian" would gain additional legitimisation in interpretation of Arendt's oeuvre. All in all, what is crucial for the current presentation is that according to the 20th century re-appropriations of the Lurianic theological narrative by the German-Jewish thinkers, the secular character of secularity seems to be the only trace of divine chosenness. As for the importance of the Arendt-Scholem correspondence for the Lurianic hypothesis, see a marvellous study of Vivian Liska (Liska 2017).

9 I elaborated this idea for the first time in an article from 2012, see (Zawisza 2012).

10 Catholic scholars lament on Arendt and blame her of being ignorant when it comes to the natural law, just like if they were unable to understand that some intelligent people can reject a hypothesis of natural law, having in mind alternative theories of human self-constitution. (See Winters 1987, pp. 197, 203, 217; Kampowski 2008, p. 265).

11 Just like in Truth and Politics, Arendt made a distinction between "politics" and "world", seeing the latter as more voluminous. 
unknown, but not in a sense that we need more knowledge to capture it fully one day; it is unknown because it is endlessly, irreversibly deepened and complicated by language and enigmatic inscriptions into inwardness. Human being is born as a stranger into nature, and for that reason she can never return to a fictive natural harmony, neither could she recognise a "natural law" emanating from the cosmos, which lost its sacral status after the Gnostic tendency of the "Jewish-Christian teaching" (Arendt 1996, p. 52) had banished cosmotheism. From then on, any normative proposal based on the Greek notion of "nature" (physis) and its "pseudo-Christian" (Arendt 1996, p. 30) adaptation under the name of "order" (ordo) as an "everlasting, forever lawful structure" (Arendt 1996, p. 61) —is invalid. Paradise remains forever lost.

This problematic finds its realisation in the section of Arendt's dissertation entitled Ordinata dilectio. It is the most unpersuasive part of the whole book-not so much because Arendt had no idea how to play it out, but because she was not convinced at all by Augustine's argumentation, and exposed her deep reservation performatively; she seemingly tried to proceed this argumentation, but the way she did so rendered it thin. It is a parody. At first glance, ordered love seems to be an antidote for previously presented, unpredictable bursts of passion towards the Other which ended with self-destruction. It is a perfect "regulatory point of reference" (Arendt 1996, p. 37) providing tools for regulations, adaptations, and ordering, applied according to the "general order of everything that is" (Arendt 1996, p. 39); in other words, according to the vision of a pagan god understood as immutable wholeness or everlasting nature. Arendt's talent for wrongheaded recapitulations made her description of ordered love turn into adverse publicity, with barely pent-up revulsion, since it is "unconcerned objectivity" that determines:

what ought to be loved. Love itself is a consequence of this determination. The same is true for the degree of intensity that love will spend on its object, depending upon the order that assigns each to its proper place. Everyone is loved as much as he ought to be, no more and no less. (Arendt 1996, p. 38)

Nature puts people in their place. No protest, no complaint, no lament is allowed. One could ask to what end such a love is promoted which treats a human being as "a mere 'thing' to be used for the true life to come" (Arendt 1996, p. 38)? The bitter truth is that there is no other answer than that: "the 'highest good' is drawn into the present and can dominate and regulate life in this world" (Arendt 1996, p. 41). It means that the Christian theological concepts of providence, natural law, and ordo caritatis are interrelated, forming a dangerous mixture by help of which some people could gain power over another and repress them, "for the good of somebody". Those who command and order, pretending that they know this "good", do not respect enigma of human singularity, fragility, and inimitableness grounded in groundless abyss of the mystery of creation epitomised by each birth. As Arendt concluded, ordered love stays "in flagrant contradiction to the very essence of love in all its forms" (Arendt 1996, p. 42), because it depersonalises the neighbour who is not recognised in his "concrete uniqueness", but "in sublime indifference regardless of what or who he is" (Arendt 1996, p. 43). ${ }^{12}$ Christian passion netted by categories of the Greek philosophy squirms in convulsive motion raging from self-sacrifice to indifference-perversion of suffering at its zenith.

It is obviously not only because of the demands of the Greek philosophy, but first of all because of "life's instability" (Arendt 1996, p. 17) that man could not find its final destination. But what Arendt recommends for human condition's instability by no means resembles traditionalist ordo. Since it is a creaturely life, finite and thus far from absolute, it needs a proper perspective, which would respect the "limitations of earthly life" (Arendt 1996, p. 27). Therefore, the sense of measure is crucial—measure not derived from extraterrestrial patterns, by means of which life "is looked upon from the outside (from outside the living person)" (Arendt 1996, p. 16), but elaborated on the basis of life's own limitations, to begin with birth and death. Arendt kept persuading that "meeting life from the outside"

12 On that basis she criticized evocation of love for humankind as abstract in On Revolution. 
(Arendt 1996, p. 12) results in blaming human life for its finitude, treating it like a malady or calamity, in the end - as evil. If one compares finite life with durability of things, not to mention prevailing forces of nature, human conditionality must look miserable and incurably tragic.

(... ) upon all this misery, philosophy smiles its empty smile and, with its outstretched index finger, shows the creature, whose limbs are trembling in fear for its life in this world, a world beyond, of which it wants to know nothing at all. For man does not at all want to escape from some chain; he wants to stay, he wants-to live. (Rosenzweig 2005, p. 9)

Influenced by Rosenzweig, Arendt continued his neues Denken, especially when she rotated the perspectives to favour singularity against Wholeness. To do so, she sometimes took liberties mocking sanctity: "For man, eternity is the future, and this fact, seen from the viewpoint of eternity, is of course a contradiction in terms" (Arendt 1996, p. 16). Absurdity helps to show how absurd is to force human beings to imitate idealised projections of absoluteness. For instance, Arendt criticized pure thinking abstracted from a living subjectivity: "From the viewpoint of life this state in which man's spirit relates to itself is a kind of death. For to the extent that we are alive and active (and desire is a form of action), we necessarily are involved in things outside ourselves and cannot be free" (Arendt 1996, p. 21). Cannot be free in an absolute sense, I should add. Our freedom is possible only in the absence of absolute. If in lieu of celebration of this conditioned freedom, man starts to desire eternity, a kind of time without space, then it poisons finitude with nostalgia for an existence freed from any movement and intermingling with matter. To that Arendt responded with a highly polemical sentence interwoven as a counterpoint between verses, in which she depicted trances of Plotinus and Augustine about eternity: "What prevents man from 'living' in the timeless present is life itself, which never 'stands still'" (Arendt 1996, p. 16). ${ }^{13}$

Arendt protected the exceptionality of human condition so that it would not dissipate into shapeless eddying of cosmic becoming. This does not mean that she avoided transcending life, crossing the boundaries of birth and death into two types of nothingness. However, as we will see, the clinching is where the observation post will be located: whether we look at the cold cosmos, or it looks at us and chills the blood.

\section{Damned Creatures}

Although the central question of the dissertation is neighbourly love, the first part deals with solipsism of the subject desiring God, while the second part concerns inversion of this longing, namely a path that an individual follows backwards, looking through his origin for the Creator. This composition itself outlines Arendt's critical stance: since only the third part opens the possibility of loving one's neighbours, in the previous ones a reader finds nothing but aporias, obstacles, impasses, and contradictions. Happiness turns out to be unreachable, life is bitter, God's grace fades-alienation in full swing. "Can life be said to exist at all?" (Arendt 1996, p. 14)—asked Arendt, leading Augustine's doubts to completion. In her mouth this "doubt" concerning life turns almost into a kind of Docetic heresy: Augustine is accused of hampering the recognition of the carnal, earthly presence of his neighbours.

The problem resides in the ideal of self-sufficiency, das Autarkieideal (Arendt 1929, p. 27). ${ }^{14}$ Philosophical vision of the absolute inherited by Augustine-immovable, omnipotent, omniscient-hangs over men as a sign that they are always inferior. Consequently, desire of eternal life, with its aspiration of being in God, with God, like God, brings about that "man's present life is being neglected for the sake of its future, and loses its meaningfulness and weight in comparison with that true life" (Arendt 1996, p. 27). Craving for timeless delight "proceeds to strip the world and all

13 That is why Arendt was critical about nunc stans also in her last work, Willing.

14 In the text I use "autarchic" as derivative from "autarchy", although its meaning as "absolute" produces additional aftersound. 
temporal things of their value and to make them relative. ( ... ) Since they will not last, they do not really exist" (Arendt 1996, p. 14).

The root of the problem lies deeper. Self-sufficiency meets its limits everywhere. Because of the dialectics of life, which continues its development due to changes, to live means to move, never standing still. ${ }^{15}$ This provokes frustration. And since God in Augustine is by definition the highest good, the only object to be blamed is life or human being, or-in a refined version-fallen human nature. Thus, Arendt's intuition leads her to locate the source of the problems articulated by Augustine in his very attitude towards life: "Once we assume the perspective that we no longer view life as 'before death' but as 'after death,' death equalizes by devaluing life as such" (Arendt 1996, p. 76).

Although Arendt discussed many influences which shaped Augustinian thought, she never mentioned Manichaeism, neither Gnosticism in general. But here it would be very much accurate to see not only Stoic and Neoplatonic dimensions in the ideal of autarchy, but also the Manichean background of some motives, like regression and withdrawal from the world no less than the shift from total concentration of inwardness to the sacrifice of the self, which Arendt called "pseudo-Christian" (Arendt 1996, p. 30). Later on, she noted the existence of some Christian type of self-denial, but without detail. ${ }^{16}$ Nevertheless, Arendt enumerated essential features of love according to Paul of Tarsus, who, unlike Augustine, had claimed: that perfection is possible already in finite life, not only in heaven; that love won't cease in eternity; that in the afterlife God will be loved by the same love through which s/he is loved (Arendt 1996, pp. 30-32). On the contrary, for Augustine the Manichean, world and creatures remain in such a deep debasement that they do not deserve to be loved. "Man should not love in this life" (Arendt 1996, p. 30), because any possible object of love cannot compare with God. Accordingly, love in any case should not be accompanied by enjoyment (frui). The only characteristic of caritas that provides people with a foretaste of eternity is fearlessness. But disappearance of the fear of death results in forgetting about mortality (Arendt 1996, p. 29), abandonment of the human condition and achievement of ataraxic indifference. ${ }^{17}$ This indifference to one's own death, however, could affect attitude towards others. Fleeing from evil nature and avoiding intense relations with people, solipsist subjectivity seeks its only refuge in God. But this god, whom the isolated individual worships so fervently in a language of philosophy, is the ancient cosmos in disguise.

\section{Indifference vs. Singularity}

Loath reference to life comes from a certain vision of the cosmos treated as a pattern and a fundament which human finitude should depend on. Worse, if the Hebrew God-philosophically dissected by theologians-adopts the attributes from the cosmic Wholeness, which was the case in the Christian theology. "I think, and hope to show, that it is precisely the notion of God as summum bonum that creates the difficulty" (Arendt 1996, p. 44)—with this statement which leaves no doubt about her intentions, Arendt closed the first part of the dissertation. In the second, "natalist" part, the quest for one's origin plays the main role. Despite the obvious fact that its appearance seems to be contradistinctively infinitesimal in comparison to the magnitude of cosmos, birth becomes the Archimedean point for a defence of a fragile process of individuation.

In the world constructed by Augustine, nobody is interested in our happiness, everyone lives alone facing death and meanwhile experiencing disillusionment because of desires. "The Creator remains forever identically the same, independent of his creation and whatever may happen within it"

15 Giorgio Agamben cannot be a legitimate continuator of Arendt's for this reason alone that his deconstruction of Western metaphysics contains aversion towards movement and moving (Agamben 2013, p. 95). For Arendt "calm quietude" (Arendt 1996, p. 19) is as rare as love, not to mention the absolute calmness which simply equals death (Arendt 1996, p. 13).

16 Arendt's general stance towards Christianity one could explain this way: when she wrote that "contempt for the world and its goods is not Christian in origin" (Arendt 1996, p. 20), she did not claim that neither Christian traditions nor ecclesiastical laws are deprived of this Grundbefindlichkeit.

17 These are cryptotheological motives inherited by Agamben from Martin Heidegger; Agamben's elaboration of limbo contains them in a nutshell. 
(Arendt 1996, p. 56). Not only does the Creator keep indifference, "the postulated eternity of Being makes beginning and end interchangeable in terms of the temporal creature's reference to its own existence" (Arendt 1996, p. 56). This was another blasphemy for Arendt, even if she was perfectly conscious about its provenance from a different religious sensibility which makes an idol of something the strongest. Having reversed perspectives, Arendt's tenderness focuses on the most unwanted element in nature, abandoned even by "God"—on a singularity:

Self-questioning (se quaerere) can thus be doubly guided: man can ask himself both about the 'whence' and the 'whither' of this existence. Although both questions ask about negations of life, the negations differ in kind. The negation 'not yet' denotes the source of life and the 'no more' denotes death. Despite their seemingly identical negativity, the past and future negations are not the same". (Arendt 1996, p. 70)

It is worth underlining that although an individual directed at origin is favoured over an individual directed at death, the former is not absolutized by Arendt, since the final vision of mankind's community, a possible modest salvation already on earth, we find in the third part of her doctoral thesis. Yet, in the end, without the loved singularities this community could be a catastrophe. That is why Arendt spoke up for any singularity, buffering "the very tendency to be" (Arendt 1996, p. 71) against laminating by cosmic indifference.

To defend singularity as such is not enough, though. Natality towers pure potentiality of becoming. ${ }^{18}$ When due to comparison with the vastness of nature "human life is divested of the uniqueness and irreversibility in which temporal sequences follow each other from birth to death", the individual does not necessarily cease to be a singularity (singulum) but loses its "autonomous significance" (Arendt 1996, p. 60). Singularities seen from the viewpoint of nature are unreservedly exchangeable "whatever beings", perfectly replicable. ${ }^{19}$ That is why they could not be loved, since love singularizes (Bielik-Robson 2015). "If man and his life are parts of some encompassing whole, they cannot be said to have an origin and their mortality has become irrelevant" (Arendt 1996, p. 62). When somebody's death does not bother us, it means that we do not love this person.

To singularize someone is like breaking the eternal cycle for a while, in order to offer him a shelter where he would escape from the double threat of nothingness surrounding finite life. The cycle of generation and perishing must be interrupted, to give a breath for life individualised, augmented, irreducible to any other. Only then the highest possible hope of conducting inimitable life would shine upon dark horizon. As was said, Arendtian vitalism does not prohibit transgressions beyond both horizons, but only because it is already well "earthed". Singularity can be self-assured always having someone on her side. Through "transmundane recollection" (Arendt 1996, p. 47), inspired and driven by the love of the world, finite life constitutes itself and consolidates, even though it demands accompanying, so that one does not let it out of sight. Perspective makes a difference. When we are imagining singularity and think about the whole time when she had been nonexistent, up until the moment of coming into the world, our concentration condenses myriad coincidences, entwining them more and more tightly and expecting the looming of a beloved shape. However, this attitude is not the first and the only reaction one can develop towards the naked fact of being-it is unpredictable like every singularity. It is always true that it might had been otherwise.

Thus, "to love the other in his mortality" (Arendt 1996, p. 96) does not mean to love death, but to truly love finite condition of creatureliness, despite death, despite everything. It is not love of mortality,

18 "The mere potentiality for something is not yet a being-intended for something in such a way that the process of becoming is guided toward it" (Jonas 1996, p. 172). That is why, on the other side of a spectrum, when Arendt conceptualised specific place of natal capacity to begin, "she did not equate spontaneity with contingency" (Kalyvas 2008, p. 224). She was not an enthusiast of contingency-it was, according to her, the price of freedom.

19 This point is completely overlooked by Agamben and Esposito, who built their theories on Deleuze's notion of singularity. "Pre-existing creation" (Arendt 1996, p. 66) and "pure createdness" (Arendt 1996, p. 68) is just a germ, the daybreak of the odyssey that subjectivity undertakes, not its last chapter. 
but of natal singular in his mortality. Love of life, even though provoked by death, exceeds mere acceptance and gets stamina from natality. Stubbornly repeating "not yet", it mobilizes all resources of "whence" against dispersion and brings previous obstacles back to prove its strength and durability. Only then challenging the truth that "human existence as such depends on something outside the human condition" (Arendt 1996, p. 49) comes out as not so terrifying. Natality and remembrance stand guard over another truth: "once called into existence, human life cannot turn into nothingness" (Arendt 1996, p. 53). Because the eternal cycle was broken, something really unpredictable came into being. That is why for the philosophy of immanence that ennobles the "sempiternal Becoming" (Arendt 1996, p. 63), natality equals mortality. It is not surprising that Aristotle's god who "never came into being" and is praised for being immutable, could not mourn. He did not risk anything, so he had nothing to lose.

\section{BDSM Theology}

Hannah Arendt as the thinker of natality does not overestimate living-towards-origin, contrary to what Agata Bielik-Robson claims (Bielik-Robson 2015). For movement directed at beginning could turn out to be "the self-denial of referring back" (Arendt 1996, p. 98). ${ }^{20}$ Even in the fragments which seem to be an apology of the return to one's own origin, she maintained awareness that "this approach depends on God's own inclination to the creature" (Arendt 1996, p. 90). But it is already clear: God (of metaphysics) has no inclinations and knows no exception. Arendt's critique is strong, but subtle. For example, she sounds very affirmatively in the statements like: "Caritas fulfils the law, because to caritas the law is no longer a command; it is grace itself. (... ) This loving acceptance reconciles the creature with its Creator" (Arendt 1996, p. 91). However, this is not such an idyll as it might look like. Arendt immediately adds a sarcastic comment: "This self-denial can only be achieved in caritas, because nothing else provides a reason for the sacrifice" (Arendt 1996, p. 91). ${ }^{21}$ Indeed, love of God has devastating effects for the subject, who "loves himself as God loves him, hating everything he has made in himself, and loving himself only insofar as he is God's creation" (Arendt 1996, p. 91). The extremism visible here is embedded in the conception of the original sin, which attempts the complete disempowerment of man. Of course, Augustine left some division of labour, so that man was not totally passive: what is evil is inscribed at the human's account, what is good occurs in the form of God's grace. ${ }^{22}$ From the anthropological point of view, it was detrimental. When in Willing Arendt returned once again to Augustine, she criticised him for incorporating "scandalous" dialectics of grace, which encourages to ignite "willed submissiveness" and a delight in painful experiences in the individual (Arendt 1978, p. 90). This comment inspired the present section, which could be

20 Arendt's critique of solipsist individual turned against the world could have had political resonance already within the Weimar context. Arendt developed secularist use of the "unavailable inwardness" (unverfügbare Innerlichkeit), while Weimar religious antimodernists (like contemporary ones do) used it for completely opposite reasons-to destroy the autonomous secular realm of the Republic, treated as an imposition of the "Western values": "Social utopias were centered around two poles; on one side around the idea of a strong state, and on the other side around the conception of an individual who should be enabled to voluntarily fulfil his duties towards the whole, based on a religiously founded morality. All of these alternative concepts had a widely identical structural core and were binding ideologies. There was indeed constant talk of freedom, conscience and personality but only in a certain sense. (...) Freedom was for the most part understood as the ability to bind and sacrifice oneself. In defining these binding ideologies-this pious nationalization of conscience-theological conceptions played a central role (Tanner 2012, p. 13). Karl Löwith put things differently, believing in the automatic political significance of inwardness, but his perspective sheds light on the issue of Arendt's early concerns. Criticizing Nazi-influenced philosophical works of the 1920s and 1930s, he stated that "the main losses were the questions regarding individual existence or-religiously speaking-the interest in spiritual salvation. Augustine's 'quaestio mihi factus sum' (I have examined myself) was no longer voiced by anyone today, but one indeed raised questions about the natural foundations of völkisch life: about soil, race, region and blood" (Löwith 1994, p. 53).

21 This sarcasm is undetectable for a Catholic reader, for whom "truly Christian caritas" occurs when a creature regresses to the Creator, "humbly admitting that he has not made himself ... " (Kampowski 2008, p. 227).

22 "To defeat the Pelagian heresy, however, Augustine abandoned a dialectical view of the relation of law to grace. On this new account, in the dialectic of willing and incapacity the latter had finally triumphed. Homo sub lege, or man under law, was divested of all capacity to will or do good. His freedom consisted only in the delectatio peccati, the lust for the sinful. No longer did Augustine speak of a serious fight against temptation" (Lazier 2008, p. 39). 
regarded as prolegomena to the psychotheological critique of religion and unguarded worship of God, which especially in Christianity is at risk of falling into idolatry of the natural order.

The cosmic indifference, represented philosophically, conceptualised divinity as a perfectly autarchic, self-centred Whole. But interconnected with the wilful Hebrew Yahweh, this god becomes monstrous. The theatre of cruelty demands not only "self-hatred" (Arendt 1996, p. 27), but also resignation from activity, since no one is able to deserve salvation (Arendt 1996, p. 29). The intrusive presence of divine grace keeps life in disgrace. "What becomes sinful here is independence as such, not a revolt of the part against the whole, but as an independent performance of submission" (Arendt 1996, p. 87). It means that even a gesture of submission is castigated as much too subjective, not to mention what unbelievable sin it would be not to adapt to the Whole (Arendt 1996, p. 65). Any perversion on the part of the creature is forbidden, so that the Sovereign develops his phantasies about absolute domination without restraint. "Creature has no power over its own being" (Arendt 1996, p. 87), he lives "keeping with ( . . ) newly felt dependence" (Arendt 1996, p. 88), which means "no longer a simple relation to God, but a direct plea for his help" (Arendt 1996, p. 89). "Contempt for self" (Arendt 1996, p. 102) comes from nothing, but a recognition of "the sinfulness of his own incapacity and inferiority to the command" (Arendt 1996, p. 89). Finally, humiliation transforms into experiencing the divine "grace" (Arendt 1996, p. 88) and "love" (Arendt 1996, p. 89). The secret lies in obeying "the command to return to Being" (Arendt 1996, p. 88), i.e., indifference, ruthlessness, and cruelty.

There are certain methods also for those who do not really enjoy pain and suffering. "Cruel lies [grausam Lügen; Rosenzweig 1921, p. 9]"23 (Rosenzweig 2005, p. 10) of philosophy (and theology altogether) are intended to cover a horrific spectacle. "The tool with which philosophy works the obstinate material until it no longer puts up resistance" (Rosenzweig 2005, p. 10), in this case is the ideal of beauty. Augustine emblazoned how cosmos was perfect and spotless so that burke all possible complaints of the creatures, the very germs of critique. "Imperishable harmonious whole" was in Augustine's eyes vested in the "splendor of eternity" (Arendt 1996, p. 59), gleaming with the "admirable beauty of the universal" (Arendt 1996, p. 60). Going from one extremity to another, Augustine, following the Manicheans on the one hand, rejected earthly reality as inferior, if not disgusting, but following Plato, Stoics, and Plotinus on the other hand, he justified overwhelming beauty of the cosmos, ${ }^{24}$ claiming that mortals cannot see this perfect, ideal harmony, just because their perspective is much too narrow. With this argument one could show disrespect to every suffering, pain, malady, illness, to any harm done. For that reason, Arendt was merciless in dragging up such horrible quotations as proof of Augustine's indifference. When he tried to explain why God allowed some people to do evil, he said that because "they might decorate the universe" (Arendt 1996, p. 61). ${ }^{25}$ Another example, this time summarized in Arendt's words, elucidates why something other than perfect Wholeness should exist at all. The indirect answer seems to be grotesque, well ..., God needed us to get some exercise: "It is the function of the parts to set and keep in motion (agere) the whole" (Arendt 1996, p. 58). This sadomasochistic predilection for the Whole, which contradicts any attention for the oppressed creatures, resonates in Plotinus, "whose thought Augustine frequently render almost verbatim" (Arendt 1996, p. 64):

If one of these parts moves according to its nature, it makes those suffer to whom this movement is against their own nature, whereas the former as parts of the whole are well. Those who cannot bear

\footnotetext{
23 Translation modified.

24 In the text Augustin und der Protestantismus from 1930 Arendt wrote: "Indeed, he never abandoned his Neo-Platonism, the legacy of Plotinus, the last Greek. He never stopped trying to understand and interpret the world in philosophical-cosmological terms" (Arendt 1994, p. 25). That is why Vecchiarelli Scott is wrong when she thinks that Neo-Platonism was one of the many influences which Augustine could balance and choose between, sometimes belittling their strength (Vecchiarelli Scott 2010, p. 15).

25 From: The Free Choice of the Will III, 11, 32.
} 
the order of the whole perish [ ... ] since they cannot escape the order [ . . ]. If, however, they could fit themselves into the order of the whole they would suffer nothing from it. (Arendt 1996, pp. 64-65)

I quote extensively in order to make evident what commentators usually prefer to obliterate, namely unconditioned consent to violence and cruelty. ${ }^{26}$ The quotation comes from the famous treaty Against the Gnostics contained in the second Ennead, where Plotinus made transparent what he regarded as the greatest danger associated with the Gnostic rebel against the cosmic piety: "blaming the whole" (Plotinus 1990, p. 249).

\section{Redemption through Sin: Defence of the Saeculum}

Already at the beginning of the dissertation Arendt lost patience, asking whether life is indeed not worth a damn. Whether vita mortalis is indistinguishable from mors vitalis, a living death? But what if "there [is-RZ] no consolation in death?" (Arendt 1996, p. 11). Whether life is so bitter that one should love death instead? And later on, with disarming sincerity, she nailed Augustine down:

Would it not then be better to love the world in cupiditas and be at home? Why should we make a desert out of this world? The justification for this extraordinary enterprise can only lie in a deep dissatisfaction with what the world can give its lovers. (Arendt 1996, p. 19)

She lamented and reproached him, because for him the human being is always "too much" or "not enough". There is any tiny place for "celebrate yourself". It would be better not to be born. What at least about "transient happiness" (Arendt 1996, p. 11)?

Nonetheless, Augustine claimed that earthly love is impossible to satisfy. Arendt lapped it up: love is indefinite which exposes infinity of desire, just as love for the world marks world's incompleteness and openness. It is nobody's fault, it is our chance and only hope. The word mundus, ${ }^{27}$ which had fallen off theology, ${ }^{28}$ Arendt lifted like a precious jewel. It glimmers with verboten glamour. "The world consists of those who love it" (Arendt 1996, p. 66). A chance of reinvention resides solely in them.

Yet, freedom is Augustine's tormentor. As well as desire. "Augustine calls this right love caritas: the 'root of all evils is cupiditas, the root of all goods is caritas.' However, both right and wrong love ( ... ) have this in common-craving desire, that is, appetitus" (Arendt 1996, p. 17). Why is this so important? Because it secures anthropology from the Manichean tendency within Augustinian thought, which strives for condemnation of the humankind. Thus, Arendt mobilised counterarguments: firstly, in selfhatred man "denies the present, mortal self that is, after all, God's creation" (Arendt 1996, p. 30); secondly, "he who does not love and desire at all is nobody" (Arendt 1996, p. 18); thirdly, "even caritas mediates between man and God in exactly the same way as cupiditas mediates between man and the world" (Arendt 1996, p. 30); fourthly, there is something more perturbing than discordant desire, namely: isolation, whom both caritas and cupiditas break (Arendt 1996, pp. 18-19).

The only interpreter who noticed and appreciated Arendt's defence of cupiditas is Lucy Tatman. ${ }^{29}$ However, I need to disagree at one point with her otherwise illuminating reading. In my opinion, it is

26 Which is not so much a question of temperament-since both serene Plotinus and impetuous Augustine agreed on legitimate violence of the Whole against its parts-but rather a logic of thought which, once set in motion on the basis of a false premise, rams everything on its way. Would it not be justified to read the case of Eichmann this way?

27 If one wanted to find biographical references, Arendt's insistence on "being of the world", de mundo (Arendt 1996, p. 66), could be matched with her predilection for Berlin as a cosmopolitan city, the first metropolis she lived in, see (Steinberg 2007). A flavour of this spirit was preserved in some languages, for instance in German weltmännisch, French mondain or Polish światowy, mirroring the theological anathema put on worldly man. Arendt's biographer characterised her as follows: "Hannah Arendt was a Weimar Berliner in social mores" (Young-Bruehl 2004, p. 240).

28 Oliver Marchart characterizes Arendt's later notion of the "Earth" as "non-theological"; however, he claims that the origin of her concept of the "world" was double, being a combination of Augustine's and Heidegger's views (Marchart 2005, pp. 33-34). In this way it comes partially from theological discussions-it was extracted from them; hence I would call it cryptotheological.

29 See especially (Tatman 2013, p. 629). 
not fortunate to call what Arendt did the "transvaluation of Augustinian values" (Tatman 2013, p. 630). If we needed to search for her progenitor, then, knowing what Karl Löwith wrote about Friedrich Nietzsche and Franz Overbeck in the end of Von Hegel zu Nietzsche (Löwith 1964), I think it would be more accurate to regard Arendt as an Overbeck's heir. It is a question of style, but also of method. In her dissertation, Arendt wrote within theology, trying to elbow through dense material and make a place for anthropological, secular sensitivity. It was necessary, because "Augustine proceeds to strip the world and all temporal things of their value and to make them relative. All worldly goods are changeable (mutabilia). Since they will not last, they do not really exist" (Arendt 1996, p. 14).

There is no comparison between Tatman's deep understanding and the mistaken theological critiques, like the one, didactic in tone, ${ }^{30}$ which sees in cupiditas losing the self, isolation and disorientation, confusion caused by desire (Vecchiarelli Scott 1988, p. 409). No doubt, since for Vecchiarelli Scott "cupiditas ( ... ) is evil itself" (Vecchiarelli Scott 1988, p. 417). I have just demonstrated that Arendt was not terrified by worldly attachments, and did not follow Augustine's panic. For her, it was more dreadful and pernicious isolation than cupiditas, which is rather always an engagement into worldly matters.

Moreover, there is the whole affirmative section in Der Liebesbegriff about dilectores mundi, whom Augustine in his less philosophical tone had regarded simply as sinners. But Arendt's analysis uncovers a positive mode of being in the world, which not only cannot be theologically smashed, but-conversely-needs to be appreciated from a theological point of view. Avoiding to directly address the human fallenness and its cause, she shifted attention and underlined that whatever the cause might have been, it is a matter of fact that humans build the world, although they did not create it. Oliver Marchart uses the concept of co-creation (mit-schaffen) in this context, and depicts human activity with the verb eingreifen, which promotes understanding of the act of coming into the world as stepping into it, intervention and interference (Marchart 2005, p. 33). ${ }^{31}$

In other words, the distinction between principium as creation of the world by God and initium as human potentiality to insert new beginnings was not Arendt's warning of man against trespassing the human condition; rather, it is a conservative predilection of reading the history of creation first as a history of men's fall and condemnation. Arendt understood the difference between God and humans without nostalgia or melancholy. Thank God we are creatures, not God himself. It means that we do not need to drag responsibility for the world as it was created, but we are responsible within the horizon of co-creation. Next to a possibility of destroying the world, there are plenty of peaceful and delightful modes of inhabiting the earth. What I think Arendt wanted to regain was closer to the Jewish attitude towards earthly reality, which is not poisoned by the obsessive concentration on human sinfulness and, consequently, does not need to project a vision of God as summum bonum. In Arendt's cryptotheological sensitivity, human beings are not totally opposed to God, as thinkers like Augustine, Karl Barth, or Eric Voegelin might suggest—indeed, Arendt rejected Augustine's blackmail of choosing between "contempt of God" or "contempt for self" (Arendt 1996, p. 102). Hence, men can be co-creators, allowed to intervene in the course of events and take responsibility for action. But the first attachment needs to be to the world, not to God. This does not mean that it should be

30 Pedagogical simplification is evident in a moralistic reading of The Human Condition, which strives to condemn modernity as an error and link Der Liebesbegriff to Arendt's later thought in a function of a theological critique of the modern age. According to David Grumett, modern lifestyle epitomises cupiditas, which leads directly to the "inversion of the right order of eternal and temporal goods" (Grumett 2000, p. 161).

31 It is impossible to imagine how this vision could be compatible with Augustine's version of God who "hated us as being such as he had not made us" (Arendt 1996, p. 92; from: Tractates on John's Gospel CX, 6). This God wants to see us in pure creatureliness understood as crude misery, the initial poverty and dependence. She behaves like a parent who can't reconcile with her children's maturity, because she feels unnecessary, thus she makes their separation impossible. In misery humankind would pray to God more willingly. That God hates our technique, medicine, our pills, lipsticks and drags. Incidentally, Arendt had her own opinion about the Vatican biopolitics under the pope Paul VI. In a letter dated 21 December 1968, she wrote to Mary McCarthy: "Poor Paul—who in addition to everything else is a political idiot; he could have left the Pill [sic!] very well alone" (Arendt and McCarthy 1995, p. 232). 
directed against God. On the other hand, it ought to be directed against any vision of God which would discourage man from taking his earthly finitude seriously, from leaving "human standard" (Arendt 1996, p. 94). No salvation or apocalypse should unbrace human life's rootedness, anchored to the Earth.

I cannot agree with Beiner when he writes: “What Augustine seeks is for human beings to 'crave' the eternal with the same 'appetite', the same intensity of feeling, with which they have always hitherto carved the things of this world" (Beiner 1997, p. 271). It is not so simple: damned creatureliness nudzhs even in amor Dei, since "'when I love my God'—says Augustine-I love not 'the beauty of bodies, not the splendour of time, not the brightness of light, ( . . ) not the sweet melodies of all kinds of songs,' yet I still 'love some kind of light, and some voice, and some odor'" (Arendt 1996, p. 25). Arendt implicitly showed in such fragments from Augustine that his isolationist ideal prevents him from elementary gratitude. He was more eager to concentrate on "independence" of those imaginations from matter, "forgetting" what he had already said about their likeness to the earthly reality. He also "forgot" about himself as an enlivened matter which carries those images.

Appetite is always disturbing, sensual, it reminds of being de mundo, merely a creature. Instead, Augustine's obsession with self-sufficiency and animosity towards matter made him dream about freedom from libido (Arendt 1996, p. 20) and pleasure (voluptas) (Arendt 1996, p. 24). Arendt ironized that, saying that whereas he had become a thinker after his friend's death, he had become a Christian because of libido (Arendt 1996, pp. 13-14). In general, in Augustine's aversion for life Arendt detected fear of "multiplicity of the world" (Arendt 1996, p. 24), of "dispersion" (Arendt 1996, p. 23), whereas for her "the field of transcendence" (Celermajer 2011, p. 8) was relocated into human relations, as Celermajer rightly observes.

Arendt's unspoken objection was that Augustine's mode of loving was full immersion, which was performed only before God. However, in the second part she evoked a more affirmative constellation of desires within Augustinian frame, swerved slightly by natalist recollection of the self. For desire is defined as certain ability, which should be awakened and inspired thanks to memory: instead of repressing it by ordo, desire should seek for happiness (Arendt 1996, pp. 48, 49, 51). Happiness is "always previously given" (Arendt 1996, p. 9), in a sense it is a gift of fate (Arendt 1996, p. 69), since it depends on others, deep relations with our earthly creators, parents, and caregivers, finally on a clandestine transmission of a sparkle of life and enigmatic word about "more life". In sum, reflection on desire beyond object-related pattern ${ }^{32}$ leads to the discovery of a "deeper and more fundamental mode of human dependence" (Arendt 1996, p. 49). And this is what an isolated individual exclusively concerned with his soul dreads the most.

It is noteworthy that for Augustine the original sin was transmitted materially by the father's libido and sperm. Only then Arendtian natalism could be properly understood unto its dark provenance. Natalism is an attempt to overcome gnosis, condensed in the Augustinian contempt for body, procreation, and sexuality. What he had called sinfulness, she called "the most crucial determinant of human existence" (Arendt 1996, p. 100). Arendt's seemingly objective description shifts accents from sin to freedom: "Man's origin is at the same time both the beginning of the man-made world in Adam's original sin and the origin of his separation from God. His descent is defined by generation and not by creation" (Arendt 1996, p. 104). To sum up what we have so far: firstly, God's separation of the creatures from nature, then analysis concentrated more on creation than on Creator ${ }^{33}$ so that finally could introduce another cut, distancing "degenerated" men from the order

32 It is only for Augustine that relation of happiness and memory demands the model of anamnesis, which links the shape the desire could take with certain divine instruction. Arendt preserved the connection with the past, but for her the fate of desire, the specific direction it heads, is not determined. She pointed at the more fundamental dependence, which results in the general affirmation of life, something occurring before full individuation.

33 "( ... ) a religious faith not in God but in creation" (Bernauer 1987b, p. 11). On the contrary, as Benjamin Lazier observes, dialectic theologians saved God, but not creation (Lazier 2008, p. 120). 
of creation. In order to say that one has to have a different understanding of what Augustine named as original sin. For Arendt it was less dramatic: "The quest for worldliness changes man's nature" (Arendt 1996, p. 18). It is a matter of fact, the fact that "man is not self-sufficient" (Arendt 1996, p. 18), nothing more and nothing less. In other words, we are not guilty that we were born this way.

One could say that Arendt did not allow this guilt complex to actuate the "inner dialectics of faith", thus she turned direction and asked about "the common ground of experience" (Arendt 1996, p. 99). The dilemmas of inwardness, known already, are dismissed here. While the first part unmasked human futuristic desire as underpinned by something that psychoanalysis could call simply death-drive, the second part ended with a failure of another movement towards God, this time origin-oriented one. But Arendt did not condemn those general orientations of the homo temporalis, ${ }^{34}$ rather, she clarified that what had caused these pointless attempts had been a mistaken starting point-in an isolated individual. For that reason, the third part deals with inter-esse, the space in-between where any kind of human relations takes its origin, "tied to the factuality of history and to the past as such" (Arendt 1996, p. 99). Since Arendt wanted to read theologems in the most secular way possible, she chose to follow Augustine in what he taught about civitas terrena, earthly city, a condition of social life with horizontal relations and reciprocal interdependence. ${ }^{35}$ Nonetheless, the contemporary reception of Arendt understands the shift from the individual to community in a simplistic way: as abandonment and renouncement. What my interpretation regains is that it was a highly dialectical shift, in which the critique of the absolutisation of the subject goes hand in hand with the defence of the process of individuation.

Arendt's analysis focuses on "the common descend from Adam, the foundation of a definite and obligatory equality among all people" (Arendt 1996, p. 100). Even if it could be called "community-in-sinfulness" (Arendt 1996, p. 102), "this civitas terrena is not arbitrarily founded and not arbitrarily dissolved" (Arendt 1996, p. 100). Continuity of generations is hard to be extinguished, because "once called into existence, human life cannot turn into nothingness" (Arendt 1996, p. 53)—-this fragment clearly shows how Arendt used theological vision of God's own promises and logic of creation in order to protect humankind from God's potential arbitrariness. She grounded this subversion of perspectives in quotidian experience: even if God created us, the first link in the chain of being are our parents, then previous generations back to Adam and Eve. "The primary experience is not that God is imperishable, but that the world is" (Arendt 1996, p. 69). "God (if indeed it is God)" (Arendt 1996, p. 78) should not feel offended that such is the first panorama of a finite being. Creaturely life is by definition limited, and to live one needs a sense of orientation within possibilities, gained by testing the boundaries of reality. The origins are always modest: "The community of all people among themselves goes back to Adam and constitutes the world; it always precedes any city of God (civitas Dei). It is a pre-existing community into which the individual comes by birth" (Arendt 1996, p. 103). It is not necessarily directed with arrogance against God-if only this is the God who draws conclusions from his actions and for that reason respects human freedom.

34 The figure of homo temporalis appeared on one of the last pages Arendt ever wrote, and Tatman suggests that in Judging the author would have been trying to establish a subjectivity based on a temporality of love (Tatman 2013, p. 633). Thus, it is unthinkable what John Kiess writes, whether one understands it theologically or as intellectualisation: "Arendt ultimately seeks to secure a place outside temporal existence" (Kiess 2016, p. 117). That she wanted to rescue singularity from the flux of events, and spontaneity from the dominant forces of causality does not mean that she sought rescue in some kind of nunc stans. She was not a dualist to think in terms of either-or.

35 But horizontal relations between people derive directly from the failure of solipsist, vertical modes of subjectivisation. That is why Bernauer is completely wrong searching for an analogy that could reconcile everything: "As creatures of the same Creator, each individual is also related to all others in an ontological relationship which is called to concretize itself in mutual commitments" (Bernauer 1987b, p. 19). It is evident here how pious intentions of the theologians result in negligence of Arendt's double negative dialectics without which cryptotheological defence of secularity is unthinkable. In the end, maybe there is nothing esoteric in all of that (Kampowski 2008, p. 23), however ... der liebe Gott wohnt im Detail. 


\section{Vita socialis (III Chapter)}

Arendt, dissatisfied by the outcomes from the first two chapters, posed a question whether one could find in Augustine "another empirical context, different in origin, that would give the neighbor a specific relevance" (Arendt 1996, p. 98). She immediately looked at "the community of faith", first generations of Christians, bonded not even by common descent, not by any "pre-existing reality in the world", but by "a specific possibility" - "the common faith" (Arendt 1996, p. 98). It would seem that a community gathered around "possibility" is an open community, which is true in a sense that it demands sharing belief, disregarding questions of provenance and gender (or at least, this is a radical realisation of community enabled by early Christianity). But this kind of inclusiveness has its hidden agenda, namely that it "demands a total response from each person" - "the community of faith demands the whole man" (Arendt 1996, p. 99). It is an invitation to live "a last and most radical possibility of being human" (Arendt 1996, p. 99), extremely detached from any worldly context.

Another problem which we can decipher as allusive is that this community, however open to converts it may be, renders every individual to be a potential co-fellow in faith (Arendt 1996, p. 99). If I understand Arendt well, she mentioned here a pressure on conversion, especially disturbing for the Jews who did not follow Jesus of Nazareth and saw neither Messiah nor Christ in him. There is no open question about the Jews, but it is obvious that Arendt asked about them too, universalizing her inquiry to "all people, even unbelievers" (Arendt 1996, p. 99), whom she put as challenge to the vision of the community limited to one faith in one God.

Here starts Arendt's Judeochristian intervention. After she questioned the boundaries of the newly formed community, whose universalism limits itself only to those who converted, then she tried a mode of interpretation which I call Marranic. Before she confronted the event of Christ's revelation, she made sure that even unbelievers (Jews among others-because from the Christian perspective Jews are also unbelievers, since they do not believe in divinity of Jesus of Nazareth) can be treated as neighbours. As we will see, referring to "a historically pre-existing reality, obliging as such" (Arendt 1996, p. 99), Arendt not only wanted to find more universal conception of the neighbourly love than the Christian one, but she did that specifically by starting to investigate new Christians about their most intimate past, reminding them that their "faith is tied to the factuality of history and to the past as such" (Arendt 1996, p. 99). One may like to read those passages philosophically, which is possible, but the very passages oblige us to read them within the context of earthly reality. This reality was the Jewishness of Jesus and Jewish origins of a part of early followers of Christ. What this strong reminder implies is not only certain solidarity and gratitude, but also it opens the ground for theological and historical discussions about the fate of Judeochristianity, a belief that historically did not become dominant, did not crystallize, yet left traces and remained intellectually provocative for both Jews and Christians, who at a certain point found themselves partings their ways.

By calling Arendt's textual strategy "Marranic" I do not claim that she was a Marrano, neither at the time of writing the dissertation nor after. My interpretation refers to the positing of the author. First of all, the name she used for Jesus of Nazareth is "Christ", as if she treated him like a Christian. This "as if" is crucial to understand the strategy. It allows Arendt to work within Christian tradition, at its core and Judaizing it. If she marked her (personal) distance from the Christian faith as a Jew (or as an unbeliever, or both), the textual effect would be less disturbing. But here we see how "the author" invades a seemingly alien territory, leaving actual persona of Hannah Arendt, the real author, aside. I call this reading a Marranic one with reference to the actual person, who wrote her dissertation and spent her student years in the context of an officially secular state and university, but actually in an environment when Christianity was still culturally dominant. But when it comes to the internal intertextual context, her dissertation could be classified as Judeochristian, meaning an attempt to imagine the beginning of the new era differently, to reinvigorate a debate about the boundaries of the new creed, its object and horizon.

Hannah Arendt had many objections to the way historical Christianity evolved from these early experiences. She initiated her discussion with the provocative sentence which orients the rest of 
her investigations: "The redeeming death of Christ did not redeem an individual but the whole (mundus), understood as the man-made world" (Arendt 1996, p. 99). Nothing more blasphemous for Augustine, whom the perspective of salvation instructed that it was only the immortal soul and not the world which deserved to be redeemed. And Augustine functions here as a representant of the official Christian theology, not as an extreme exception, but as the rule.

Be that as it may, the first step-claiming that salvation concerns the existing world, and not even mentioning any future one, but claiming additionally that the soul is definitely not at stake-entails the second step, namely turning the perspective from salvation to creation and from Christ to Adam. The typical Christian dilemmas and convulsions of a soul trembling about its future is replaced by the interest in the germ of a social bond, the basis for the neighbourly love, which here is not even love, but "affection" (Arendt 1996, p. 100).

When in The Origins Arendt would distance itself from the naturalised conception of equality of all men, it would seem that she left behind equality guaranteed by nature or God. Nevertheless, what she detected in Augustine as "a definite and obligatory equality among all people" (Arendt 1996, p. 100) is not a fact-it is a wish (one should wish others to be equal with her) and an obligation (one ought to do so). Although God created men from one man to give incontestable proof of the common descent, it is not from nature, but through nature that equality gains its validity: "This kinship creates an equality neither of traits nor of talents, but of situation" (Arendt 1996, p. 100). This situation is mortality, common "fate" (Arendt 1996, p. 100). But it is not to be treated with resignation and sadness-what in Augustine is called "original sin" for Arendt presents itself as just "the most crucial determinant of human existence" (Arendt 1996, p. 100). What she borrows from Augustine-and it will not change after the war-is that equality is not a natural fact, but a question of recognition. Here it is in front of God because it is still a reconstruction of theological texts, but the crucial thing is that even having God the Creator at the bottom of the narrative equality is not a matter of fact, and it cannot be taken for granted. In other words, even if God sees everybody as equal, people are expected to discover equality of sharing the human condition on their own. They are encouraged or obliged to do so. Obligation, however, is understood as wishing others to be equal to myself, believing in that, and actively changing the situation in this direction: "all people were to be united not only by the likeness of nature, but also by the affection of kinship" (Arendt 1996, p. 100). ${ }^{36}$

It will be characteristic for Arendt's understanding of the human rights that although we know today that the genetical unity of the whole humankind is a fact, it could only inspire us to cherish humanity of the species. But it cannot be the decisive argument. ${ }^{37}$ Unlike Hans Jonas, who quarrelled with Arendt about that point and who placed ethical grounding in the biology of organic life, she rather thought that this kind of proof is not only unnecessary, but that it contradicts the way human society is being formed. In reference to "mutual interdependence" and social life based on a belief-trust, she wrote: "The continued existence of humankind does not rest on the proof. Rather, it rests on necessary belief, without which social life would become impossible" (Arendt 1996, p. 101).

The proper, radical, otherworldly grounded, thus non-Judaic notion of neighbourly love comes with the revelation of Christ, which Arendt described with certain reluctance, seeing in it-which was already noticed before- - the most extreme way of being, but the one which could fail because of its high hopes. Besides, in this fragment Arendt reconstructed Augustine's path of reasoning. But more importantly, it seems that she did not want to simply replace the Jewish model with a Christian one.

36 From: The City of God, XIV: 1.

37 Shin Chiba makes errors twice by stating: "In later years she even has rejected the Judaeo-Christian belief in the unitary origin of the human race, a position that she obviously endorsed in her earliest work, Der Liebesbegriff bei Augustin" (Chiba 1995, p. 515). First of all, Arendt did not directly harbour humanity of humankind in the divine origin, even in her dissertation. Secondly, she never abandoned the idea of the unity of humankind. Without the subtlety of cryptotheological inspiration one cannot understand how it was smuggled into her understanding of the human rights. 
After a short passage about the new Christian community based on freely chosen commitments and obligations (Arendt 1996, p. 102), she returned to the saeculum and the humanity originating in Adam:

In the society founded on Adam man has made himself independent of the Creator. He depends on other persons and not on God. The human race as such originates in Adam and not in the Creator. (...) The world's independence from God rests on historicity, that is, on mankind's own origin, which possesses its own legitimacy. The world's sinfullness derives from its origin independent of God. (Arendt 1996, p. 103)

With this passage Hannah Arendt made a shift which by many will be interpreted in terms of total secularisation of her philosophy. For me, however, it is a perfect realisation of her cryptotheology. God is not rejected or neglected-it is only from a dogmatic position that it could seem to be like that. Conversely, it is the moment when double negative dialectics works within monotheistic legacy in order to legitimize the plurality of mankind. From "the simple sameness of the God" (Arendt 1996, p. 99) firstly sprang Adam, as an idea of mankind unified, and then the dispersion of Men from Man occurred. It is an alternative narrative about Creation, which one may find in Kabbalah (Scholem 1965). There is no contradiction between this version and the fact that at the beginning of The Human Condition Arendt opted for one of the two versions of the creation of man in Genesis, which depicted the creation Adam and Eve at the same time (not Adam first and Eve from his flesh), because Arendt referred in Der Liebesbegriff to the non-canonical sources too - characteristically, she did not leave any footnote introducing a quaint figure of Adam before Adam. The Adam whom Arendt could have had in mind while writing Der Liebesbegriff was Adam Kadmon from the Kabbalah, not the actual Adam from the first couple. Adam Kadmon was a mediator between God's oneness and human plurality. God created this ideal image in his own likeness and then dispersed it indirectly. Although Arendt did not evoke Kabbalistic sources openly, ${ }^{38}$ one can understand her otherwise obscure speculation referring to the Jewish traditions:

it is the origin of the whole race transmitted indirectly to the individual by generation. The first man, the source, hands down this indirectness by way of all men through the historically made world. Indirectness alone first establishes the equality of all people. (Arendt 1996, p. 104)

Adam before Adam helps to resolve the problem haunting Christian metaphysics, namely how to explain that something different from God came into being at all. If God is so perfect in his isolation, why did he create the world? Or, how to affirm human plurality contrasting with his oneness? Christian radicalism personified in Augustine had resolved those dilemmas at the expense of man. But in Judeochristian reading which Arendt offered, there is no necessity to contrast human and God like one contrasts evil and good (not to mention that in the Kabbalah the reflection about God's internal evil, hidden and safely remaining in his essence, was not something unheard of). When we change perspective, however, and start with the perception Arendt proposed, what we have at first is human irreducible plurality; going back through generations we could reach the imagined first couple and then, it seems, monotheistic religious imagination needed an image of one man to build a passage between earthly reality (dyadic structure as the simplest one possible to reproduce) and God's inaccessibility. Adam Kadmon would be then a condensation of human dreams about a universal, diverse unity. At the same time, unique status of God is preserved and-looking chronologically this time, in the way his uniqueness is transmitted to men-mediated. Before differentiation in multitude and dispersion there is the last moment, which will remain embedded in the memory of humankind, reminding it of the "distinctive human origin" (Arendt 1996, p. 104), a double genealogy. It implies double negative dialectics, which could distance singularity from God in order to secure her "being

38 It would have been quite odd after all, analysing Augustine. However, Arendt in her dissertation sometimes seemed to refer to some esoteric thought. 
of man among men" (Arendt 1996, p. 104), but also distance her from a given community thanks to referring back to something that exceeds actuality and immanence. According to Arendt, Christianity accentuated rather the latter-"being of man as a creature" (Arendt 1996, p. 104), standing individually before God in isolation and alienation, believing falsely that humans need to imitate autarkic ideal.

The rest of the third chapter Arendt devoted to discussing the Christian community of faith. It is a complicated part, which could be misunderstood without the Marranic hypothesis. The author rarely trespasses mere reconstruction, but from time to time she commented critically. The rhythm of the presentation consists of longer passages of reconstruction, followed by interventions. They do not add much to the arguments gathered so far. It is evident, however, that Arendt completely disregarded taking salvation into account. In her reading, Christianity already entered into the zone of salvation, the Kingdom had already come, so the only important issue is the neighbour. She emphasized that salvation had not abolished mortality. Although she engaged deeply in the meanders of Christian neighbourly love, what counted for her most is that "the neighbor's relevance is not tied to Christianity. The binding power of the common faith in Christ is secondary. Faith in Christ redeems the past and only the common past can make the faith a common faith. This past alone is common to all" (Arendt 1996, p. 107).

\section{Whose Is That God?}

In the letter from 14 January 1945 to Gershom Scholem, Hannah Arendt presented herself as follows: "Ich bin ( . . . ) ein Epikaeures" (Arendt and Scholem 2010, p. 57). It is an epithet iridescent with various meanings, attributed by the Jewish communities to Hellenised Jews, heretics, epicureans or unbelievers. Relying on this polymorphous self-ascription, one should not expect any "religious correctness" ${ }^{\prime 39}$ from Arendt. She betrayed both traditions, Jewish and Christian, looking for "the speculative conditions for a philosophy of freedom" (Arendt 1978, pp. 145-46).

When it comes to God, she was very fastidious. Her remarks, like: "God (if indeed it is God)" (Arendt 1996, p. 78)—signify "healthy suspicion of the transcendent" (Neiman 2001, p. 70). Arendt did not accept God, who appears as deus ex machina, ready to command (Arendt 1996, p. 39). For some people who regard themselves as "orthodox", it could seem to be hutzpah. But I find in her art of distancing oneself from the absolute a kind of respect for God's enigma and a deep understanding of the symmetrical enigma of men. The figure of chiasmus incarnates the way their interconnectedness functions. God of Arendtian speculation resides on the antipodes of the theological vision of divinity preferred by Augustine:

as Supreme Being, God is the quintessence of Being, namely self-sufficiency, which needs no help from the outside and actually has nothing outside itself. So strong is Augustine's dependence upon these non-Christian currents of thought that he even uses them occasionally for a description of God: 'God needs no assistance from anything else in the act of creation as though he were one who did not suffice himself.' Undoubtedly, insofar as Augustine defines love as a kind of desire, he hardly speaks as a Christian. (Arendt 1996, pp. 20-21) ${ }^{40}$

For Arendt things present themselves contrarily: "Man was originally created into the world and, in spite of this election, this fact of being in the world separates him from God, that is, from pure being" (Arendt 1996, p. 80). For Augustine, to say that God could be deficient was blasphemous. According to Arendt, deficient God would be the only one who could fit to human deficiency, incompleteness, and openness. Creatureliness is torn between two kinds of nothingness. It is neither being, nor

39 This example seems to be sufficient: "The redeeming death of Christ did not redeem an individual but the whole world (mundus), understood as the man-made world" (Arendt 1996, p. 99). So much was her attention for the world, that she not only profaned Christian salvation, but also death, which she saw as "the loss of the world" (Arendt 1996, p. 33).

40 The error made by Danielle Celermajer is, thus, astonishing: "she assumed that the Neoplatonic characterizations of the God of the Jews accurately represented the ontological structure of the Hebraic universe (and God)" (Celermajer 2011, p. 10). Nothing more contrary to everything Arendt said about Neoplatonism. 
nothingness, but living in relations (Arendt 1996, p. 52). Living in-between, but at the edge of nothingness, demands some limits and buffer zones, otherwise "conscious entity" (Arendt 1996, p. 50) could not crystallise. This would not be possible without antinaturalism: distant, almost forgotten transcendence sets immanent reality aside. Nonetheless, a God who offered a space for something other than himself does not expect praise. His discreet leaving was intended, instead, to avert human gaze from absoluteness and to concentrate it on the world, inhabited by our neighbours.

Even joking sarcastically, or maybe especially then, Hannah Arendt treated theology seriously, as the absolute can at any moment invade politics in the only form absoluteness comes: violence. For that reason, I am sceptical about Samuel Moyn's recapitulation of Arendt's aim: "Secularization is precisely the attempt not to escape from the authority and the sanction with which the absolute provides politics but to find nonreligious version of them" (Moyn 2008, p. 75). Even if it were so, then, in order to cope responsibly with monotheistic legacy ${ }^{41}$ in politics, we need the cryptotheological defence of the secular world.

Funding: Narodowe Centrum Nauki (National Science Centre, Poland): grant no. 2016/20/T/HS1/00244.

Conflicts of Interest: The author declares no conflict of interest. The founding sponsors had no role in the design of the study; in the collection, analyses, or interpretation of data; in the writing of the manuscript, and in the decision to publish the results.

\section{References}

Adler, Laure. 2008. Śladami Hannah Arendt. Translated by Janina Aleksandrowicz. Warszawa: Wydawnictwo Książkowe Twój Styl. First published 2005.

Agamben, Giorgio. 2013. Opus Dei: An Archaeology of Duty. Translated by Adam Kotsko. Stanford: Stanford University Press.

Arendt, Hannah. 1929. Der Liebesbegriff bei Augustin: Versuch einer Philosophischen Interpretation. Berlin: Julius Springer.

Arendt, Hannah. 1978. Willing. In The Life of the Mind. New York: Harcourt Brace Jovanovich.

Arendt, Hannah. 1994. Essays in Understanding, 1930-1954. Edited by Jerome Kohn. New York: Harcourt, Brace \& Co.

Arendt, Hannah. 1996. Love and Saint Augustine. Edited and with an Interpretive Essay by Joanna Vecchiarelli Scott and Judith Chelius Stark. Chicago: University of Chicago Press.

Arendt, Hannah, and Karl Jaspers. 1992. Hannah Arendt/Karl Jaspers Correspondence, 1926-1969. Edited by Lotte Kohler and Hans Saner. Translated by Robert, and Rita Kimber. New York: Harcourt Brace Jovanovich. First published 1985.

Arendt, Hannah, and Mary McCarthy. 1995. Between Friends: The Correspondence of Hannah Arendt and Mary McCarthy, 1949-1975. Edited and with an Introduction by Carol Brightman. New York: Harcourt Brace.

Arendt, Hannah, and Gershom Scholem. 2010. Der Briefwechsel. Edited by Marie Luise Knott, with Assistance of David Heredia. Berlin: Jüdischer Verlag.

Armenteros, Carolina. 1999. Hannah Arendt, Rahel Varnhagen and the beginnings of Arendtian political philosophy. The Journal of Jewish Thought and Philosophy 8: 81-118. [CrossRef]

Beiner, Ronald. 1997. Love and worldliness: Hannah Arendt's reading of St. Augustine. In Hannah Arendt: Twenty Years Later. Edited by Larry May and Jerome Kohn. Cambridge: MIT Press.

41 I find Jane Anna Gordon's emphasis put on "Arendt's anomalously positive appraisal of polytheism” (Gordon 2009, p. 330) overestimated and shallow. A statement that "political theology of democratic life" can be built only on polytheistic premises does not exhaust the complexity and ambiguous character of the remarks made by Arendt about religious traditions. Of course, she admitted that the political model of sovereignty, which she contested, is embedded in a monotheistic image of God, but nevertheless-as my interpretative frame aspires to show-it was not a simple rejection of monotheism, but a heterodox pluralisation of this model. Precisely the same efforts of Jewish thinkers were described by Gershom Scholem in his studies on the Kabbalah: to defend the secular world by means of theology, avoiding an accusation of ideological reductionism by indicating the fact that "the hidden tradition" of Hebraic religion encapsulated the impulse of amor mundi. 
Bernauer, James W. 1987a. Amor Mundi: Explorations in the Faith and Thought of Hannah Arendt. Edited by James W. Bernauer. Boston, Dordrecht and Lancaster: Martinus Nijhoff Publishers.

Bernauer, James W. 1987b. The faith of Hannah Arendt: amor mundi and its critique-assimilation of religious experience. In Amor Mundi: Explorations in the Faith and Thought of Hannah Arendt. Edited by James W. Bernauer. Boston, Dordrecht and Lancaster: Martinus Nijhoff Publishers.

Biale, David. 2011. Not in the Heavens: The Tradition of Jewish Secular Thought. Princeton: Princeton University Press.

Bielik-Robson, Agata. 2014. Jewish Cryptotheologies of Late Modernity: Philosophical Marranos. London and New York: Routledge, Taylor \& Francis Group.

Bielik-Robson, Agata. 2015. L'amour fort comme la mort: Les Juifs contre Heidegger (sur la question de la finitude). La Règle du Jeu 58/59: 529-60.

Boyle, Patrick. 1987. Elusive neighborliness: Hannah Arendt's interpretation of Saint Augustine. In Amor Mundi: Explorations in the Faith and Thought of Hannah Arendt. Edited by James W. Bernauer. Boston, Dordrecht and Lancaster: Martinus Nijhoff Publishers.

Celermajer, Danielle. 2011. Hebraic dimensions of Hannah Arendt's thought. Journal of Modern Jewish Studies 10: 3-22. [CrossRef]

Chacón, Rodrigo. 2012. Hannah Arendt in Weimar: beyond the theological-political predicament? In The Weimar Moment: Liberalism, Political Theology, and Law. Edited by Leonard V. Kaplan and Rudy Koshar. Lanham: Lexington Books.

Chiba, Shin. 1995. Hannah Arendt on love and the political: Love, friendship and citizenship. The Review of Politics 57: 505-35. [CrossRef]

Clarke, Barry, and Lawrence Quill. 2009. Augustine, Arendt, and Anthropy. Sophia: International Journal for Philosophy of Religion, Metaphysical Theology and Ethics 48: 253-65. [CrossRef]

Gordon, Jane Anna. 2009. Hannah Arendt's political theology of democratic life. Political Theology 10: 325-39. [CrossRef]

Grumett, David. 2000. Arendt, Augustine and Evil. Heythrop Journal 41: 154-69. [CrossRef]

Jonas, Hans. 1996. Mortality and Morality: A Search for the Good after Auschwitz. Edited and with an Introduction by Lawrence Vogel. Evanston: Northwestern University Press.

Kalyvas, Andreas. 2008. Democracy and the Politics of the Extraordinary: Max Weber, Carl Schmitt, and Hannah Arendt. Cambridge and New York: Cambridge University Press.

Kampowski, Stephan. 2008. Arendt, Augustine, and the New Beginning: The Action Theory and Moral Thought of Hannah Arendt in the Light of Her Dissertation on St. Augustine. Grand Rapids and Cambridge: William B. Eerdmans Pub. Co.

Kiess, John. 2016. Hannah Arendt and Theology. London and New York: Bloomsbury T\&T Clark.

Lazier, Benjamin. 2008. God Interrupted: Heresy and the European Imagination between the World Wars. Princeton: Princeton University Press.

Liska, Vivian. 2017. German-Jewish Thought and Its Afterlife: A Tenuous Legacy. Bloomington: Indiana University Press.

Löwith, Karl. 1964. From Hegel to Nietzsche: The Revolution in Nineteenth-Century Thought. Translated by David E. Green. New York: Holt, Rinehart and Winston. First published 1941.

Löwith, Karl. 1994. My Life in Germany before and after 1933: A Report. Translated by Elizabeth King. London: Athlone Press. First published 1986.

Marchart, Oliver. 2005. Neu Beginnen: Hannah Arendt, die Revolution und die Globalisierung. With a preface by Linda Zerilli. Wien: Turia + Kant.

Moyn, Samuel. 2008. Hannah Arendt on the Secular. New German Critique 35: 71-96. [CrossRef]

Neiman, Susan. 2001. Theodicy in Jerusalem. In Hannah Arendt in Jerusalem. Edited by Steven E. Aschheim. Berkeley: University of California Press.

Plotinus. 1990. Ennead II. Translated by Arthur Hilary Armstrong. Cambridge and London: Harvard University Press.

Rosenzweig, Franz. 2005. The Star of Redemption. Translated by Barbara E. Galli. Madison: University of Wisconsin Press. First published 1921.

Rosenzweig, Franz. 1921. Der Stern der Erlösung. Frankfurt am Main: J. Kauffmann Verlag.

Savarino, Luca. 1999. Quaestio mihi factus sum: Una lettura heideggeriana di 'Il concetto d'amore in Agostino'. In Hannah Arendt. Introduction and Edited by Simona Forti. Milano: Bruno Mondadori. 
Scholem, Gershom. 1965. On the Kabbalah and its Symbolism. Translated by Ralph Manheim. New York: Schocken Books.

Sontheimer, Kurt. 2005. Hannah Arendt: Der Weg einer grossen Denkerin. München: Piper.

Steinberg, Michael P. 2007. Hannah Arendt and the cultural style of the German Jews. Social Research 74: 879-902. Taminiaux, Jacques. 1997. The Thracian Maid and the Professional Thinker: Arendt and Heidegger. Translated and Edited by Michael Gendre. Albany: State University of New York Press. First published 1992.

Tanner, Klaus. 2012. Protestant Revolt against Modernity. In The Weimar Moment: Liberalism, Political Theology, and Law. Edited by Leonard V. Kaplan and Rudy Koshar. Lanham: Lexington Books.

Tassin, Étienne, and de Véronique Albanel. 2010. Préface. In Amour du monde: Christianisme et politique chez Hannah Arendt. Paris: Les Éditions du Cerf.

Tatman, Lucy. 2013. Arendt and Augustine: More than one kind of love. Sophia 52: 625-35. [CrossRef]

Vecchiarelli Scott, Joanna. 1988. 'A detour through Pietism:' Hannah Arendt's on St. Augustine's philosophy of freedom. Polity 20: 394-425. [CrossRef]

Vecchiarelli Scott, Joanna. 2010. What St. Augustine taught Hannah Arendt about 'how to live in the world:' caritas, natality and the banality of evil. Collegium: Studies Across Disciplines in the Humanities and Social Sciences 8: 67-85.

Weir, Todd H. 2015. The Christian front against godlessness: Anti-secularism and the demise of the Weimar Republic, 1928-1933. Past and Present 229: 201-38. [CrossRef]

Winters, Francis X. 1987. The Banality of virtue: Reflections on Hannah Arendt's reinterpretation of political ethics. In Amor Mundi: Explorations in the Faith and Thought of Hannah Arendt. Edited by James W. Bernauer. Boston, Dordrecht and Lancaster: Martinus Nijhoff Publishers.

Wolin, Richard. 2001. Heidegger's Children: Hannah Arendt, Karl Löwith, Hans Jonas, and Herbert Marcuse. Princeton: Princeton University Press.

Young-Bruehl, Elisabeth. 2004. Hannah Arendt: For Love of the World, 2nd ed. New Haven and London: Yale University Press. First published 1982.

Zawisza, Rafał. 2012. Ocalić to, co się da: Witalistyczna interpretacja rozprawy doktorskiej Hanny Arendt pt. 'O pojęciu miłości u Augustyna'. Praktyka Teoretyczna 6: 327-45. [CrossRef]

(C) 2018 by the author. Licensee MDPI, Basel, Switzerland. This article is an open access article distributed under the terms and conditions of the Creative Commons Attribution (CC BY) license (http:/ / creativecommons.org/licenses/by/4.0/). 